\title{
Catalogue of Psocoptera (Insecta: Psocodea) types housed in the collection of the Museu de Zoologia da Universidade de São Paulo
}

\author{
Alberto Moreira da Silva Neto ${ }^{1,3}$, Alfonso Neri García Aldrete ${ }^{2}$ \& José Albertino Rafael ${ }^{1,4}$ \\ ${ }^{1}$ Instituto Nacional de Pesquisas da Amazônia (INPA), Coordenação de Pesquisas em Entomologia (CPEN), \\ Programa de Pós-Graduação em Entomologia (PPG-ENT). Manaus, AM, Brasil. \\ ${ }^{2}$ Universidad Nacional Autónoma de México (UNAM), Instituto de Biología, Departamento de Zoología. México, D.F., México. \\ ORCID: http://orcid.org/0000-0001-7214-7966.E-mail: anga@ib.unam.mx \\ ${ }^{3}$ ORCID: http://orcid.org/0000-0002-4522-3756. E-mail: bio.alberto@gmail.com \\ ${ }^{4}$ ORCID: http://orcid.org/0000-0002-0170-0514. E-mail: jarafael@inpa.gov.br
}

\begin{abstract}
A catalogue of type specimens of Psocoptera (Insecta: Psocodea) deposited in the collection of the Museu de Zoologia da Universidade de São Paulo, São Paulo, Brazil, is presented and updated to February, 2019. 45 holotypes and 47 paratypes of 52 species were found, included in the suborders Psocomorpha and Trogiomorpha, and listed in the families Amphipsocidae, Asiopsocidae, Caeciliusidae (infraorder Caeciliusetae); Lachesillidae and Pseudocaeciliidae (infraorder Homilopsocidea); Philotarsidae (infraorder Philotarsetaea) Hemipsocidae, Myopsocidae and Psocidae (infraorder Psocetae); Ptiloneuridae (infraorder Epipsocetae), and Lepidopsocidae (infraorder Atropetae). The taxa are presented alphabetically by suborders, infraorders, families, subfamilies, tribes and genera, followed by species (updated to the valid name), bibliographic citation, type category, description of the type condition with collection number and method of preservation. When necessary, comments are added.
\end{abstract}

Key-Words. Psocids; List of type material; Scientific collections; Taxonomy.

\section{INTRODUCTION}

Psocoptera are also known as Corrodentia or Copeognatha and have no popular name in Brazil, being known in other countries as book lice, bark lice or psocids. These insects are small, measuring from 1 to $10 \mathrm{~mm}$ in length and feed on algae, lichens, fungi and organic fragments (Smithers, 1991); they are considered important in the environment for the recycling of debris (Arnett, 2000). Yoshizawa \& Lienhard (2010) showed that Psocoptera is not a monophyletic group. To maintain monophyly, the former orders Psocoptera and Phthiraptera are now placed in the order Psocodea. However, as true lice and psocids have distinct habits, and are studied by different methods and by different experts, Psocoptera is still treated as an order in the traditional way, but mentioned in Psocodea. In the present paper we have adopted the practice mentioned above. The Catalogue of the Fauna of Brazil (Silva-Neto \& García Aldrete, 2015) specifically in Psocoptera, lists for Brazil 456 species in 93 genera and 30 families.

The scientific collection of the Museu de Zoologia da Universidade de São Paulo (MZUSP),
São Paulo, Brazil, includes more than 10 million specimens, being the largest and most important depository of Neotropical fauna in Brazil and in South America. Additional information on the collection is available at www.mz.usp.br. Following a recommendation of the International Code of Zoological Nomenclature (ICZN, 1999: 72F.4), the present paper provides a catalogue with information on 92 type specimens included in 52 species of Psocoptera.

\section{MATERIAL AND METHODS}

The information given for each species was taken from labels, and corroborated with original description or published articles. The words cerrado or cerradão are present on some labels. Cerrado is a phyto- and biogeographic area of Brazil, characterized especially by the savannah biome, but also by seasonal forest. Cerradão is a variation of Cerrado. In this list, the names of suborders, infraorders, families, subfamilies, tribes, genera, and species are presented in alphabetical order.

The following data are provided for type specimens: genus, species epithet (both updated 
when needed for valid names), author, year of publication, page number in which the species name first appeared, figure(s), subsequent citation when there was a new combination or some nomenclatural correction of the epithet, category of the type specimen with sex and collection locality, condition of types with current MZSP registration number and method of preservation. In particular cases, the sex of some paratypes was not identified, because the specimens are partly destroyed, or lack the apex of the abdomen. When necessary comments were added.

\section{RESULTS}

45 holotypes and 47 paratypes of 52 species were found, in two suborders (Psocomorpha and Trogiomorpha), six infraorders (Caeciliusetae, Homilopsocidea, Philotarsetae, Psocetae, Epipsocetae and Atropetae) and 11 families (Amphipsocidae, Asiopsocidae, Caeciliusidae, Lachesillidae, Philotarsidae, Pseudocaeciliidae, Hemipsocidae, Myopsocidae, Psocidae, Ptiloneuridae and Lepidopsocidae).

\section{List of type specimens \\ Psocoptera Shipley, 1904 \\ Psocomorpha Badonnel, 1951 \\ Caeciliusetae Pearman, 1936 \\ Amphipsocidae Pearman, 1936 \\ Amphipsocinae Pearman, 1936 \\ Dasypsocini Mockford, 1978 \\ Dasypsocus Enderlein, 1906 \\ Dasypsocus roesleri (New \& Thornton)}

Kolbea roesleri New \& Thornton, 1975: 42, figs. 55-58.

Dasypsocus roesleri (New \& Thornton, 1975); Mockford, 1996: 39.

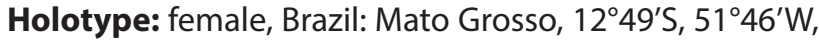
Cerrado, dead palm foliage, 29.X.1968, T.R. N[ew].

Condition of holotype: Right fore- and hindwing, right antenna and right hind leg mounted on one slide (without number); subgenital plate, gonapophyses, clunium, paraprocts and epiproct mounted in another slide (without number). Thorax and remaining parts in a separate micro-vial with ethanol (MZSP 0002101).

\section{Asiopsocidae Mockford \& García Aldrete, 1976 Notiopsocus Banks, 1913 \\ Notiopsocus neotropicus (Machado- Alisson \& Papavero)}

Lenkoella neotropica Machado-Alisson \& Papavero, 1962: 312, figs. 1-11.

Notiopsocus neotropicus (Machado-Alisson \& Papavero); New, 1973: 128, figs. 14-21.
Holotype: female, Brazil: Mato Grosso, Utiariti (Rio Papagaio), VIII.1961, (Karol Lenko).

Allotype: male, same date as the holotype.

Paratypes: 18 females and 4 males, same date as the holotype.

Condition of holotype: Specimen not dissected, stored in a separate micro-vial with ethanol (MZSP 000001).

Condition of Allotype: Specimen not dissected (missing abdomen), stored in a separate micro-vial with ethanol (MZSP 000001).

Condition of $\mathbf{4}$ male paratypes: Specimens not dissected, stored in a separate micro-vial with ethanol (MZSP 000002).

Condition of 18 female paratypes: Specimens not dissected, stored in a separate microvial with ethanol (MZSP 000002)

Comments: In the original publication, the authors claim that they deposited in the collection MZUSP, 19 female paratypes and 7 male paratypes.

\section{Caeciliusidae Mockford, 2000 \\ Caeciliusinae Mockford, 2000 \\ Coryphacini Mockford, 2000 \\ Coryphaca Enderlein, 1910 \\ Coryphaca matona (New \& Thornton)}

Dypsocus matonus New \& Thornton, 1975: 41, figs. 51-54. Coryphaca matona (New \& Thornton); Mockford, 1996: 26.

Holotype: female, Brazil: Mato Grosso, $12^{\circ} 49^{\prime} \mathrm{S}, 51^{\circ} 46^{\prime} \mathrm{W}$, cerradão, on bark, 12.IV.1960, T.R. N[ew].

Condition of holotype: Right fore- and hindwing and right hind leg mounted on one slide (№ 69270); subgenital plate, gonapophyses, clunium, paraprocts and epiproct mounted in another slide (№ 69270). Thorax and remaining parts in a separate micro-vial with ethanol (MZSP 000230).

Valenzuela Navás, 1924 Valenzuela andeanus (New \& Thornton)

Caecilius andeanus New \& Thornton, 1975: 28, figs. 9, 1-6. Valenzuela andeanus (New \& Thornton); Mockford, 2000: 353.

Paratypes: male, Colombia: Bogotá, 2,750 m., on gorselike plant, 10.Il.1967, I.W.B.T.; female, Ecuador, mts N.W. of Quito, 3,200-3,350 m., 16.II.1967, I.W.B.T. 
Condition of male paratype: Right fore- and hindwing, right antenna and right hind leg mounted on one slide (without number); hypandrium, phallosome, paraprocts and epiproct mounted in another slide (without number). Thorax and remaining parts in a separate micro-vial with ethanol (MZSP 000249).

Condition of female paratype: Right fore- and hindwing, right antenna and right hind leg mounted on one slide (without number); subgenital plate, gonapophyses, paraprocts and epiproct mounted in another slide (without number). Thorax and remaining parts in a separate micro-vial with ethanol (MZSP 000249).

\section{Valenzuela claristigma (New \& Thornton)}

Caecilius claristigma New \& Thornton, 1975: 38, figs. 8, 37-40.

Valenzuela claristigma (New \& Thornton); Mockford, 2000: 355.

Holotype: female, Brazil: Mato Grosso, $12^{\circ} 49^{\prime} \mathrm{S}, 51^{\circ} 46^{\prime} \mathrm{W}$, gallery forest litter, 01.X.1968, T.R. N[ew].

Condition of holotype: Right fore- and hindwing, right antenna and right hind leg mounted on one slide (without number); subgenital plate, gonapophyses, clunium, paraprocts and epiproct mounted in another slide (without number). Thorax and remaining parts in a separate micro-vial with ethanol (MZSP 000251).

\section{Valenzuela clayae (New \& Thornton)}

Caecilius clayae New \& Thornton, 1975: 39, figs. 41-44. Valenzuela clayae (New \& Thornton); Mockford, 2000: 381.

Holotype: female, Brazil: Mato Grosso, $12^{\circ} 49^{\prime} \mathrm{S}, 51^{\circ} 46^{\prime} \mathrm{W}$, campo, on grasses, 23.IX.1968, T.R. N[ew].

Condition of holotype: Right fore- and hindwing, right antenna and right hind leg mounted on one slide (without number); subgenital plate, gonapophyses, clunium, paraprocts and epiproct mounted in another slide (without number). Thorax and remaining parts in a separate micro-vial with ethanol (MZSP 000252).

\section{Valenzuela cinalus (New \& Thornton)}

Caecilius cinalus New \& Thornton, 1975: 35, figs. 10, 29-32. Valenzuela cinalus (New \& Thornton); Mockford, 2000: 350 .

Holotype: female, Brazil: Mato Grosso, $12^{\circ} 49^{\prime} \mathrm{S}, 51^{\circ} 46^{\prime} \mathrm{W}$, discarded roofing palm (Mauritiu) on ground, 11.II.1969, T.R. N[ew].
Condition of holotype: Right fore- and hindwing, right antenna and right hind leg mounted on one slide (without number); subgenital plate, gonapophyses, clunium, paraprocts and epiproct mounted in another slide (without number). Thorax and remaining parts in a separate micro-vial with ethanol (MZSP 000250).

\section{Valenzuela micans (New \& Thornton)}

Caecilius micans New \& Thornton, 1975: 33, figs. 12, 20-24. Valenzuela micans (New \& Thornton); Mockford, 2000: 354.

Holotype: female, Brazil: Mato Grosso, $12^{\circ} 49^{\prime} \mathrm{S}, 51^{\circ} 46^{\prime} \mathrm{W}$, dry forest, undergrowth, 16.I.1969, T.R. N[ew].

Condition of holotype: Right fore- and hindwing, right antenna and right hind leg mounted on one slide (without number); subgenital plate, gonapophyses, clunium, paraprocts and epiproct mounted in another slide (without number). Thorax and remaining parts in a separate micro-vial with ethanol (MZSP 000253).

\section{Valenzuela paradistinctus (New \& Thornton)}

Caecilius paradistinctus New \& Thornton, 1975: 34, figs. 12, 25-28.

Valenzuela paradistinctus (New \& Thornton); Mockford, 2000: 352.

Holotype: female, Brazil: Mato Grosso, $12^{\circ} 49^{\prime} \mathrm{S}, 51^{\circ} 46^{\prime} \mathrm{W}$, dead palm fronds, 23.X.1968, T.R. N[ew].

Condition of holotype: Right fore- and hindwing, right antenna and right hind leg mounted on one slide (without number), subgenital plate, gonapophyses, clunium, paraprocts and epiproct mounted in another slide (without number). Thorax and remaining parts in a separate micro-vial with ethanol (MZSP 000254).

\section{Valenzuela tuberculatus (New \& Thornton)}

Caecilius tuberculatus New \& Thornton, 1975: 30, figs. 7, 13-15.

Valenzuela tuberculatus (New \& Thornton); Mockford, 2000: 356

Holotype: male, Brazil: Mato Grosso, $12^{\circ} 49^{\prime} \mathrm{S}, 51^{\circ} 46^{\prime} \mathrm{W}$, gallery forest, sweeping undergrowth, 31.I.1969, T.R. $\mathrm{N}[\mathrm{ew}]$.

Condition of holotype: Right fore- and hindwing, right antenna and right hind leg mounted on one slide (without number); hypandrium, phallosome, paraprocts and epiproct mounted in another slide (without number). Thorax and remaining parts in a separate micro-vial with ethanol (MZSP 000255). 


\section{Homilopsocidea Pearman, 1936 \\ Lachesillidae Pearman, 1936 \\ Lachesillinae Pearman, 1936 \\ Lachesilla Westwood, 1840 \\ Lachesilla bicornata New \& Thornton}

Lachesilla bicornata New \&Thornton, 1975: 43, figs. 59-64.

Holotype: female, Brazil: Mato Grosso, $12^{\circ} 49^{\prime} \mathrm{S}, 51^{\circ} 46^{\prime} \mathrm{W}$, Cerrado, disturbed (roadside) vegetation, Borreria sp., 20.IX.1968, T.R.N.

Condition of holotype: Right fore- and hindwing, right hind leg, right antenna and right half of the head with labrum mounted on one slide (without number); subgenital plate, gonapophyses, paraprocts and epiproct mounted in another slide (without number). Thorax and remaining parts in a separate micro-vial with ethanol (MZSP 000217).

\section{Lachesilla marginata New \& Thornton}

Lachesilla marginata New \& Thornton, 1975: 45, figs. 69-72.

Holotype: female, Brazil: Mato Grosso, $12^{\circ} 49^{\prime} \mathrm{S}, 51^{\circ} 46^{\prime} \mathrm{W}$, Cerrado, vegetation by side of road, 20.IX.1968, T.R.N.

Condition of holotype: Right fore- and hindwing and two legs mounted on one slide (without number); subgenital plate, ninth sternum, gonapophyses, paraprocts and epiproct mounted in another slide (without number). An empty micro-vial with ethanol (MZSP 000213).

\section{Lachesilla valvula New \& Thornton}

Lachesilla valvula New \& Thornton, 1975: 44, figs. 65-68.

Holotype: female, Brazil: Mato Grosso, $12^{\circ} 49^{\prime} \mathrm{S}, 51^{\circ} 46^{\prime} \mathrm{W}$, Cerrado, on bark, 08.IV.1969.

Condition of holotype: Forewing and hindwing mounted on one slide (without number); subgenital plate, gonapophyses, clunium, paraprocts and epiproct mounted in another slide (without number). Thorax and remaining parts in a separate micro-vial with ethanol (MZSP 000211).

\section{Lachesilla sclera New \& Thornton}

Lachesilla sclera New \& Thornton, 1975: 47, figs. 75-79.

Paratype: female, Ecuador, $4 \mathrm{~km} \mathrm{~N}$. of Ambato, 2,500 m., 18.II.1967, I.W.B. Thornton.

Condition of paratype: Forewing, right antenna and right hind leg mounted on one slide (without number); subgenital plate, ninth sternum, gonapophyses, para- procts and epiproct mounted in another slide (without number). Thorax and remaining parts in a separate micro-vial with ethanol (MZSP 000227).

\section{Pseudocaeciliidae Pearman, 1936 \\ Pseudocaeciliinae Pearman, 1936 Scytopsocus Roesler, 1940 Scytopsocus medialis New \& Thornton}

Scytopsocus medialis New \& Thornton, 1975: 50, figs. 85-88.

Holotype: female, Brazil: Mato Grosso, $12^{\circ} 49^{\prime} \mathrm{S}, 51^{\circ} 46^{\prime} \mathrm{W}$, cerrado, on bark, 17.IV.1969, (T.R.N.).

Condition of holotype: Right fore- and hindwing, right antenna and right hind leg mounted on one slide (without number); subgenital plate, gonapophyses, clunium, paraprocts and epiproct mounted in another slide (without number). Thorax and remaining parts in a separate micro-vial with ethanol (MZSP 000247).

\section{Philotarsetae Yoshizawa \& Johnson, 2014 Philotarsidae Pearman, 1936 \\ Aaroniellinae Lienhard \& Smithers, 2002 Aaroniella Mockford, 1951 Aaroniella recta New \& Thornton}

Aaroniella recta New \& Thornton, 1975: 57, figs. 109-112.

Holotype: female, Brazil: Mato Grosso, $12^{\circ} 49^{\prime} \mathrm{S}, 51^{\circ} 46^{\prime} \mathrm{W}$; on bark, cerradao, 25.III.1969, (T.R.N.).

Condition of holotype: Right fore- and hindwing, right antenna and right hind leg mounted on one slide (without number); subgenital plate, gonapophyses, clunium, paraprocts and epiproct mounted in another slide (without number). Thorax and remaining parts in a separate micro-vial with ethanol (MZSP 000245).

\section{Psocetae Pearman, 1936 \\ Hemipsocidae Pearman, 1936 \\ Hemipsocus Selys-Longchamps, 1872 \\ Hemipsocus pallidus New \& Thornton}

Hemipsocus pallidus New \& Thornton, 1975: 58, figs. 113-116.

Holotype: female, Brazil: Santa Catarina: Xavantina, dead palm fronds on ground, 21-26.I.1969, T.R.N.

Condition of holotype: Right fore- and hindwing, right antenna and right hind leg mounted on one slide (without number); subgenital plate, gonapophyses, clunium, paraprocts and epiproct mounted in another slide (without number). Thorax and remaining parts in a separate micro-vial with ethanol (MZSP 000246). 


\section{Myopsocidae Pearman, 1936 \\ Lichenomima Enderlein, 1910 Lichenomima pulchella (New \& Thornton)}

Myopsocus pulchellus New \& Thornton, 1975: 75, figs. 175-178.

Lichenomima pulchella (New \& Thornton); Mockford, 1982: 217.

Holotype: female, Brazil: Mato Grosso, $12^{\circ} 49^{\prime} \mathrm{S}, 51^{\circ} 46^{\prime} \mathrm{W}$, in flight, late afternoon, 16.II.1969, (T.R.N.).

Condition of holotype: Right fore- and hindwing, right antenna and right hind leg mounted on one slide (without number); subgenital plate, gonapophyses, clunium, paraprocts and epiproct mounted in another slide (without number). Thorax and remaining parts in a separate micro-vial with ethanol (MZSP 000216).

\section{Myopsocus Hagen, 1866 Myopsocus minor (New \& Thornton)}

Phlotodes minor New \& Thornton, 1975: 78, figs. 179-186. Myopsocus minor (New \&Thornton); Mockford, 1982: 215.

Holotype: female, Brazil: Mato Grosso, $12^{\circ} 49^{\prime} \mathrm{S}, 51^{\circ} 46^{\prime} \mathrm{W}$ cerrado, dead foliage, 07.I.1969, (T.R.N.).

Male paratype: same data as the holotype.

Condition of holotype: Right fore- and hindwing, right antenna and right hind leg mounted on one slide (without number); subgenital plate, gonapophyses, clunium, paraprocts and epiproct mounted in another slide (without number). Thorax and remaining parts in a separate micro-vial with ethanol (MZSP 000256).

Condition of paratype: Right fore- and hindwing, right antenna and right hind leg mounted on one slide (without number); hypandrium, phallosome, paraprocts and epiproct mounted in another slide (without number). Thorax and remaining parts in a separate micro-vial with ethanol (MZSP 000257).

\section{Psocidae Hagen, 1865 \\ Amphigerontiinae Kolbe, 1880 \\ Amphigerontiini Kolbe, 1880 \\ Amphigerontia Kolbe, 1880 \\ Amphigerontia alticola New \& Thornton}

Amphigerontia alticola New \& Thornton, 1975: 59, figs. 117-124.

Paratypes: three females. Colombia: Bogotá, 2,750 m., on gorse-like plant, 10.II.1967, (I.W.B.T.).

Condition of the three paratypes: female 1, specimen not dissected, dehydrated, stored in a separate micro ep- pendorf with ethanol (№ 518); female 2, specimen not dissected, stored in a separate micro eppendorf with ethanol (№ 517); female 3, specimen not dissected, stored in a separate micro eppendorf with ethanol (№ 513). All the micro eppendorfs stocked in a glass bottle with ethanol (MZSP 000260).

\section{Blaste Kolbe, 1883 Blaste alfineta New}

Blaste alfineta New, 1972: 204, figs. 24-27.

Holotype: male, Brazil: Paraná. nr. Curitiba, in house, 12.III.1970, O.W. Richards.

Condition of holotype: Right fore- and hindwing, right antenna and right hind leg mounted on one slide (№ 69289); hypandrium, phallosome, paraprocts and epiproct mounted in another slide (№ 69289). Thorax and remaining parts in a separate micro-vial with ethanol (MZSP 000231).

\section{Blaste forcepata (New)}

Amphigerontia forcepata New, 1972: 195, figs. 1-7. Blaste forcepata (New); Mockford, 1996.

Holotype: female, Brazil: Mato Grosso, $12^{\circ} 49^{\prime} \mathrm{S}, 51^{\circ} 46^{\prime} \mathrm{W}$, swept from cerrado vegetation, 14.IX.1968, T.R. New.

Condition of holotype: Right fore- and hindwing, right antenna and right hind leg mounted on one slide (№ 6811); subgenital plate, gonapophyses, clunium, paraprocts and epiproct mounted in another slide (№ 6811). Thorax and remaining parts in a separate micro-vial with ethanol (MZSP 000261).

\section{Blaste macrura (New)}

Blaste (Blastopsocidus) macrurus New, 1972: 201, figs. 16-19.

Blaste macrura (New); Mockford, 1991: 274.

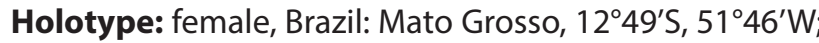
cerradão, on bark, 25.III.1969, T.R. New.

Condition of holotype: Right fore- and hindwing, right antenna and right hind leg mounted on one slide (№ 69221); subgenital plate, gonapophyses, clunium, paraprocts and epiproct mounted in another slide (№ 69221). Thorax and remaining parts in a separate micro-vial with ethanol (MZSP 000232).

\section{Blaste obscura (New)}

Amphigerontia obscura New, 1972: 198, figs. 8-11. Blaste obscura (New); Mockford, 1996: 71. 
Holotype: female, Brazil: Mato Grosso, $12^{\circ} 49^{\prime} \mathrm{S}, 51^{\circ} 46^{\prime} \mathrm{W}$; cerrado, on bark, 19.IV.1969, T.R. New.

Condition of holotype: Right fore- and hindwing, right antenna and right hind leg mounted on one slide (№ 69284); subgenital plate, gonapophyses, clunium, paraprocts and epiproct mounted in another slide (№ 69284). Thorax and remaining parts in a separate micro-vial with ethanol (MZSP 000262).

\section{Blaste richardsi New}

Blaste richardsi New, 1972: 202, figs. 20-23.

Holotype: male, Brazil: Paraná. nr. Curitiba, in house, 12.III.1970, O.W. Richards.

Condition of holotype: Right fore- and hindwing, right antenna and right hind leg mounted on one slide (without number); hypandrium, phallosome (anteriorly broken in half), paraprocts and epiproct mounted in another slide (without number). Thorax and remaining parts in a separate micro-vial with ethanol (MZSP 000233).

\section{Blastopsocidus brasiliensis (New)}

Blaste (Blastopsocidus) brasiliensis New, 1972: 199, figs. 12-15.

Blastopsocidus brasiliensis (New, 1972); Smithers, 1972.

Holotype: female, Brazil: Mato Grosso, $12^{\circ} 49^{\prime} \mathrm{S}, 51^{\circ} 46^{\prime} \mathrm{W}$; gallery forest litter, 01.X.1968, T.R.N.

Condition of holotype: Right fore- and hindwing, right antenna and right hind leg mounted on one slide (№ 69277b); subgenital plate, gonapophyses, clunium, paraprocts and epiproct mounted in another slide (№ 69277b). Thorax and remaining parts in a separate micro-vial with ethanol (MZSP 000251).

\section{Psocinae Hagen, 1865 \\ Metylophorini Roesler, 1943 \\ Metylophorus Pearman, 1932 \\ Metylophorus bishopi New}

Metylophorus bishopi New, 1972: 213, figs. 50-56.

Holotype: female, Brazil: Mato Grosso, $12^{\circ} 49^{\prime} \mathrm{S}, 51^{\circ} 46^{\prime} \mathrm{W}$, cerradão, on bark, 08.IV.1969, T.R. New.

Condition of holotype: Right fore- and hindwing, right antenna and right hind leg mounted on one slide (№ 69260); subgenital plate, gonapophyses, clunium, paraprocts and epiproct mounted in another slide (№ 69260). Thorax and remaining parts in a separate micro-vial with ethanol (MZSP 000223).

\section{Metylophorus ctenatus New}

Metylophorus ctenatus New, 1972: 215, figs. 57-60.

Holotype: male, Brazil, Mato Grosso, $12^{\circ} 49^{\prime} \mathrm{S}, 51^{\circ} 46^{\prime} \mathrm{W}$, gallery forest, on dead branch, 01.Il.1969, T.R. New.

Condition of holotype: Right fore- and hindwing, right antenna and right hind leg mounted on one slide (№ 6986A); hypandrium, phallosome, paraprocts and epiproct mounted in another slide (№ 6986A). Thorax and remaining parts in a separate micro-vial with ethanol (MZSP 000224).

\section{Ophthalmopsocus Roesler, 1943 Ophthalmopsocus pallidus (New)}

Metylophorus pallidus New, 1972: 217, figs. 61-64. Ophthalmopsocus pallidus (New); Mockford, 1991: 273.

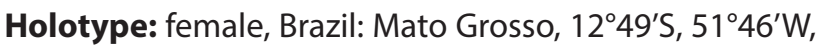
cerradão, on bark, 26.III.1969, T.R. New.

Condition of holotype: Right fore- and hindwing, right antenna and right hind leg mounted on one slide (№ 69224); subgenital plate, ninth sternum, gonapophyses, clunium, paraprocts and epiproct mounted in another slide (№ 69224). Thorax and remaining parts in a separate micro-vial with ethanol (MZSP 000225).

\section{Ptyctini Mockford, 1993 \\ Indiopsocus Mockford, 1974 Indiopsocus sinuatistigma (New)}

Ptycta sinuatistigma New, 1972: 223, figs. 77-80. Indiopsocus sinuatistigma (New); Mockford, 1996.

Holotype: female, Brazil: Mato Grosso, $12^{\circ} 49^{\prime} \mathrm{S}, 51^{\circ} 46^{\prime} \mathrm{W}$; cerrado, living vegetation, 18.X.1968, T.R. New.

Condition of holotype: Right fore- and hindwing right antenna and right hind leg mounted on one slide (№ 68156); subgenital plate, gonapophyses, clunium, paraprocts and epiproct mounted in another slide (№ 68156). Thorax and remaining parts in a separate micro-vial with ethanol (MZSP 000241).

\section{Indiopsocus expansus (New \& Thornton)}

Ptyca expansa New \& Thornton, 1975: 71, figs. 160-162. Indiopsocus expansus (New \&Thornton); Mockford, 1985:21.

Paratypes: two males, Colombia: Bogotá, 2,750 m., on gorse-like plant, midday, 10.II.1967, (I.W.B.T.).

Condition of paratype 1: Right fore- and hindwing, right antenna and right hind leg mounted on one slide (№ 511); 
hypandrium, phallosome, paraprocts and epiproct mounted in another slide (№ 511). Thorax and remaining parts in a separate microvial with ethanol (MZSP 000236).

Condition of paratype 2: Right fore- and hindwing, right antenna and right hind leg mounted on one slide (№ 510); hypandrium mounted in another permanent slide (№ 510). Thorax and remaining parts in a separate micro-vial with ethanol (MZSP without number).

\section{Psocomesites Roesler, 1943 Psocomesites spinosus (New \& Thornton)}

Psocus spinosus New \& Thornton, 1975: 68, figs. 145-151. Psocomesites spinosus (New \& Thornton); Badonnel, 1986: 213.

Paratypes: three males and one specimen without sex identified. Ecuador: mts N.W. of Quito, 3,350 m., beating, 16.II.1967, (I.W.B. T[hornton]).

Condition of the three male paratypes: male 1, specimen not dissected, extremely resected, stored in a separate micro eppendorf with ethanol (№ 521); male 2, specimen not dissected, extremely resected, stored in a separate micro eppendorf with ethanol (№ 522); male 3, specimen not dissected, stored in a separate micro eppendorf with ethanol (№ 522). All three micro eppendorfs stocked in a glass bottle with ethanol (MZSP 000218).

Condition of paratype without sex identified: specimen without wings, legs, antennae and abdomen, stored in a separate micro eppendorf with ethanol (№ 521A) inside the same glass bottle mentioned above (MZSP 000218).

Comments: In the original paper the authors chose 4 male specimens and 1 female specimen as paratypes. For this reason it is not possible to deduce the sex of the specimen without abdomen mentioned above. Probably the paratype specimen without sex identified was mounted on a slide, not found. There was a label stating that the ethanol in the glass bottle (mentioned above) had completely evaporated and was replaced in 02.IX.1999.

\section{Ptycta Enderlein, 1925 Ptyca elena New \& Thornton, 1975}

Ptycta elena New \& Thornton, 1975: 69, figs. 152-159.

Paratypes: two females, Venezuela, Santa Elena (on coast), 25 m., on a dead bush, 28.VI.1967 (I.W.B.T.); a male with same data.

Condition of female paratype 1: Right fore- and hindwing, right antenna and right hind leg mounted on one slide (№ 545); ninth sternum, subgenital plate, gonapophyses, paraprocts and epiproct mounted in anoth- er slide (№ 545). Thorax and remaining parts in a separate micro-vial with ethanol (MZSP 000235).

Condition of female paratype 2: Right fore- and hindwing and right antenna mounted on one slide (№ 548); ninth sternum, subgenital plate, gonapophyses, paraprocts and epiproct mounted in another slide (№ 548). Thorax and remaining parts in a separate micro-vial with ethanol (MZSP 000235).

Condition of male paratype: Right fore- and hindwing, right antenna and right hind leg mounted on one slide (№ 542); hypandrium, phallosome, paraprocts and epiproct mounted in another slide (№ 542). Thorax and remaining parts in a separate micro-vial with ethanol (MZSP 000235).

\section{Ptycta lunulata New}

Ptycta lunulata New, 1972: 220, figs. 69-72.

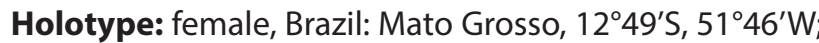
cerradão, on bark, 17.IV.1960, T.R. New.

Condition of holotype: Right fore- and hindwing, right antenna (broken into three pieces) and right hind leg mounted on one slide (№ 69280); subgenital plate, gonapophyses, clunium, paraprocts and epiproct mounted in another slide (№ 69280). Thorax and remaining parts in a separate micro-vial with ethanol (MZSP 000237).

\section{Ptycta reticulata New}

Ptycta reticulata New, 1972: 221, figs. 73-76.

Holotype: female, Brazil: Mato Grosso, $12^{\circ} 49^{\prime} \mathrm{S}, 51^{\circ} 46^{\prime} \mathrm{W}$, "Dry forest", on dead foliage, 01.III.1969, T.R. New.

Condition of holotype: Right fore- and hindwing, right antenna and right hind leg mounted on one slide (№ 69160); subgenital plate, gonapophyses, clunium, paraprocts and epiproct mounted in another slide (№ 69160). Thorax and remaining parts in a separate micro-vial with ethanol (MZSP 000240).

\section{Ptycta pearmani New}

Ptycta pearmani New, 1972: 218, figs. 65-68.

Holotype: female, Brazil: Mato Grosso, $12^{\circ} 49^{\prime} \mathrm{S}, 51^{\circ} 46^{\prime} \mathrm{W}$, "Dry forest", on dead foliage, 01.III.1969, T.R. New.

Paratype: female, same data as the holotype, but 01.IV.1969.

Condition of holotype: Right fore- and hindwing, right antenna and right hind leg mounted on one slide 
(№ 69180); subgenital plate, gonapophyses, clunium, paraprocts and epiproct mounted in another slide (№ 69180). Thorax and remaining parts in a separate micro-vial with ethanol (MZSP 000238).

Condition of paratype: Right fore- and hindwing, and right antenna mounted on one slide (№ 69240); subgenital plate, gonapophyses, paraprocts and epiproct mounted in another slide (№ 69240). Thorax and remaining parts in a separate micro-vial with ethanol (MZSP 000239).

\section{Steleops Enderlein, 1910 \\ Steleops maculatus (New)}

Steleops maculata New, 1972: 224, figs. 81-84.

Steleops maculatus (New); Lienhard \& Smithers, 2002: 460.

Holotype: female, Brazil: Mato Grosso, $12^{\circ} 49^{\prime} \mathrm{S}, 51^{\circ} 46^{\prime} \mathrm{W}$, Dry forest, on bark, 12.IV.1969, T.R. New.

Condition of holotype: Right fore- and hindwing, right antenna and right hind leg mounted on one slide (№ 69269); subgenital plate, gonapophyses, clunium, paraprocts and epiproct mounted in another slide (№ 69269). Thorax and remaining parts in a separate micro-vial with ethanol (MZSP 000220).

\section{Steleops pulcher (New)}

Steleops pulchra New, 1972: 226, figs. 85-88.

Steleops pulcher (New); Lienhard \& Smithers, 2002: 460.

Holotype: female, Brazil: Mato Grosso, $12^{\circ} 49^{\prime} \mathrm{S}, 51^{\circ} 46^{\prime} \mathrm{W}$; gallery forest, in water trap, 16.IX.1968, T.R. New.

Condition of holotype: Right fore- and hindwing, and right hind leg mounted on one slide (№ 6827); subgenital plate, gonapophyses, clunium, paraprocts and epiproct mounted in another slide (№ 6827). Thorax and remaining parts in a separate micro-vial with ethanol (MZSP 000214).

\section{Trichadenotecnum Enderlein, 1909 Trichadenotecnum pichincha New \& Thornton}

Trichadenotecnum pichincha New \& Thornton, 1975: 73, figs. 167-174.

Paratypes: two males and three specimens without sex identified. Ecuador: mts N.W. of Quito, 3,350 m., beating, 16.II.1967, (I.W.B.T.).

Condition of the two male paratypes: male 1 , specimen not dissected, resected, stored in a separate micro eppendorf with ethanol (№ 536); male 2, specimen not dissected, extremely resected, stored in a separate micro eppendorf with ethanol (№ 531). The two micro eppendorfs stocked in a glass bottle with ethanol (MZSP 000226)

Condition of three paratypes without sex identified: specimen 1, without abdomen, stored in a separate micro eppendorf with ethanol (№ 535); specimen 2, without abdomen and wings, stored in a separate micro eppendorf with ethanol (№ 533); specimen 3, only with a small part of the thorax and the right wings, stored in a separate micro eppendorf with ethanol (№ 534). The three micro eppendorfs stored inside the glass bottle mentioned above (MZSP 000226).

Comments: In the original paper the authors chose 8 male and 4 female specimens as paratypes. For this reason, it is not possible to deduce the sex of the specimens without abdomen mentioned above. Probably the paratype specimens without identification of sex were mounted on slides, not found.

\section{Trichadenotecnum roesleri New, 1972}

Trichadenotecnum roesleri New, 1972: 228, figs. 89-95.

Holotype: female, Brazil: Mato Grosso, $12^{\circ} 49^{\prime} \mathrm{S}, 51^{\circ} 46^{\prime} \mathrm{W}$; cerrado, on bark, 17.IV.1969, T.R. New.

Condition of holotype: Right fore- and hindwing, and right hind leg mounted on one slide (№ 69272); subgenital plate, gonapophyses, clunium, paraprocts and epiproct mounted in another slide (№ 69272). Thorax and remaining parts in a separate micro-vial with ethanol (MZSP 000222).

\section{Trichadenotecnum sinuatum New}

Trichadenotecnum sinuatum New, 1972: 230, figs. 96-103.

Holotype: female, Brazil: Mato Grosso, $12^{\circ} 49^{\prime} \mathrm{S}, 51^{\circ} 46^{\prime} \mathrm{W}$; cerradão, on dead palm foliage, 16.IV.1969, T.R. New.

Condition of holotype: Right fore- and hindwing, and right hind leg mounted on one slide (№ 69277); subgenital plate, gonapophyses, clunium, paraprocts and epiproct mounted in another slide (№ 69277). Thorax and remaining parts in a separate microvial with ethanol (MZSP 000221).

\section{Trichadenotecnum shawi Yoshizawa \& García Aldrete}

Trichadenotecnum shawi Yoshizawa \& García Aldrete, 2010: 62, figs. 1-2.

Holotype: male, Brazil: Goiás, Araguaia River Expedition, $8.1 \mathrm{~km}$ N of Aruana, 28.VIII.1992, Malaise trap, coll. Scott R. Shaw. 
Condition of holotype: both forewings, one hindwing hypandrium, phallosome, clunium, paraprocts and epiproct mounted on one slide in Euparal (without number). Thorax and remaining parts in a separate micro-vial with glycerol (without number).

Missing parts: Compound eyes.

Comments: The authors comment in the original publication that the specimen was cleared with Proteinase $\mathrm{K}$ and perhaps due to this the compound eyes disappeared and the remaining unmounted parts became extremely hyaline.

\section{Thyrsophorini Kolbe, 1882 \\ Cerastipsocus Kolbe, 1884 \\ Cerastipsocus beaveri New}

Cerastipsocus beaveri New, 1972: 205, figs. 28-34.

Holotype: female, Brazil: Mato Grosso, $12^{\circ} 49^{\prime} \mathrm{S}, 51^{\circ} 46^{\prime} \mathrm{W}$, gallery forest, on foliage, 09.XII.1968, R.A. Beaver.

Paratype: male, same data as the holotype.

Condition of holotype: Right fore- and hindwing, right antenna and right hind leg mounted on one slide (№ 68244); subgenital plate, ninth sternum, gonapophyses, clunium, paraprocts and epiproct mounted in another slide (№ 68244). Thorax and remaining parts in a separate micro-vial with ethanol (MZSP 000244).

Condition of paratype: Right fore- and hindwing, right antenna and right hind leg mounted on one slide (№ 6899); hypandrium, phallosome, paraprocts and epiproct mounted in another slide (№ 6899). Thorax and remaining parts in a separate micro-vial with ethanol (MZSP 000258).

\section{Cerastipsocus kolbei New}

Cerastipsocus kolbei New, 1972: 208, figs. 35-38.

Holotype: female, Brazil: Mato Grosso, $12^{\circ} 49^{\prime} \mathrm{S}, 51^{\circ} 46^{\prime} \mathrm{W}$ bred from nymph found on dead branch, gallery forest, 01.II.1969, T.R. New.

Condition of holotype: Right fore- and hindwing, right antenna and right hind leg mounted on one slide (№ 69107); subgenital plate, ninth sternum, gonapophyses, clunium, paraprocts and epiproct mounted in another slide (№ 69107). Thorax and remaining parts in a separate micro-vial with ethanol (MZSP 000259).

\section{Psococerastis Pearman, 1932 Psococerastis hageni New}

Psococerastis hageni New, 1972: 209, figs. 39-45.
Holotype: female, Brazil, Mato Grosso, $12^{\circ} 49^{\prime} \mathrm{S}, 51^{\circ} 46^{\prime} \mathrm{W}$ "Dry forest", living foliage, 15.IX.1968, T.R. New.

Condition of holotype: Right fore- and hindwing, right antenna and right hind leg mounted on one slide (№ 6824); subgenital plate, ninth sternum, gonapophyses, clunium, paraprocts and epiproct mounted in another slide (№ 6824). Thorax and remaining parts in a separate micro-vial with ethanol (MZSP 000242).

\section{Epipsocetae Pearman, 1936 \\ Ptiloneuridae Roesler, 1940 \\ Triplocania Roesler, 1940}

Triplocania lamasi Silva-Neto, Rafael \& García Aldrete

Triplocania lamasi Silva-Neto, Rafael \& García Aldrete, 2014: 78, figs. 1-7.

Holotype: male, Brazil. Mato Grosso. Poconé. Pousada sitio do seu Afrânio. Observation tower (16³6'24"S, $\left.56^{\circ} 43^{\prime} 25^{\prime \prime} \mathrm{W}\right), 19.1 .2013$, Light trap, A.M. Silva-Neto; 1 male paratype (MZSP); same data and collector as the holotype.

Condition of holotype: Right fore- and hindwing, right antenna, right lacinial tip, right hind leg, hypandrium, phallosome, paraprocts and epiproct mounted on one slide (without number). Thorax and remaining parts in a separate micro-vial with glycerin. Final storage of the specimens in "CD box" as described by Silva-Neto et al. (2016).

Condition of paratype: Right fore- and hindwing, right antenna, right lacinial tip, right hind leg, hypandrium, phallosome, paraprocts and epiproct mounted on one slide (without number). Thorax and remaining parts in a separate micro-vial with glycerin. Final storage of the specimens in "CD box" as described by Silva-Neto et al. (2016).

\section{Trogiomorpha Roesler, 1940 \\ Atropetae Pearman, 1936 \\ Lepidopsocidae Enderlein, 1903 \\ Lepidopsocinae Enderlein, 1903 \\ Echmepteryx Aaron, 1886 \\ Echmepteryx (Thylacopsis) angusta New}

Echmepteryx (Thylacopsis) angusta New, 1975: 92, figs. 31-40.

Holotype: female, Brazil: Mato Grosso, $12^{\circ} 49^{\prime} \mathrm{S}, 5^{\circ} 46^{\prime} \mathrm{W}$ dry forest, litter, 14.X.1968, T.R. N[ew].

Condition of holotype: Right fore- and hindwing, and right hind leg mounted on one slide (№ 68137); subgenital plate, gonapophyses, clunium, paraprocts and epiproct mounted in another slide (№ 68137). Thorax and remaining parts in a separate micro-vial with ethanol (MZSP 000229). 


\section{Echmepteryx (Thylacopsis) bishopi New}

Echmepteryx (Thylacopsis) bishopi New, 1975: 90, figs. 19-24.

Holotype: female, Brazil: Mato Grosso, $12^{\circ} 49^{\prime} \mathrm{S}, 51^{\circ} 46^{\prime} \mathrm{W}$, gallery forest, on dead branches on ground, 15.IV.1969, T.R. N[ew].

Condition of holotype: Right fore- and hindwing, and right hind leg mounted on one slide (№ 69276); subgenital plate, gonapophyses, clunium, paraprocts and epiproct mounted in another slide (№ 69276). Thorax and remaining parts in a separate micro-vial with ethanol (MZSP 000228).

\section{Echmepteryx (Thylacopsis) fuscata New}

Echmepteryx (Thylacopsis) fuscata New, 1975: 91, figs. $25-30$.

Holotype: female, Brazil: Mato Grosso, $12^{\circ} 49^{\prime} \mathrm{S}, 51^{\circ} 46^{\prime} \mathrm{W}$, cerradão, on bark, 12.IV.1960, T.R. N[ew].

Condition of holotype: Right fore- and hindwing, and right hind leg mounted on one slide (№ 69270); subgenital plate, gonapophyses, clunium, paraprocts and epiproct mounted in another slide (№ 69270). Thorax and remaining parts in a separate micro-vial with ethanol (MZSP 000230).

\section{Perientominae Enderlein, 1903 \\ Proentomum Badonnel, 1949 Proentomum pulvillata (New)}

Nepticulomima pulvillata New, 1975: 86, figs. 1-6. Proentomum pulvillata (New, 1975); Mockford, 2005: 203.

Holotype: female, Brazil: Mato Grosso, $12^{\circ} 49^{\prime} \mathrm{S}, 51^{\circ} 46^{\prime} \mathrm{W}$, on decaying thatching (Mauritia fronds), 07.IV.1969, T.R. New.

Condition of holotype: Right fore- and hindwing, and right hind leg mounted on one slide (№ 69257); subgenital plate, gonapophyses, clunium, paraprocts and epiproct mounted in another (№ 69257). Thorax and remaining parts in a separate micro-vial with ethanol (MZSP 000212).

\section{Soa Enderlein, 1904 Soa violacea New}

Condition of holotype: Right fore- and hindwing, and right hind leg mounted on one slide (№ 6965); subgenital plate, gonapophyses, clunium, paraprocts and epiproct mounted in another slide (№ 6965); head and two legs mounted in another slide (№ 6965). Thorax and remaining parts in a separate micro-vial with ethanol (MZSP 000219).

\section{Thylacellinae Roesler, 1944 Notolepium Enderlein, 1910 Notolepium brasiliense New}

Notolepium brasiliense New, 1975: 87, figs. 7-12.

Holotype: female, Brazil: Mato Grosso, $12^{\circ} 49^{\prime} \mathrm{S}, 51^{\circ} 46^{\prime} \mathrm{W}$, on discarded thatch (Syagrus sp.) on ground, 05.II.1969, T.R. New.

Condition of holotype: Right fore- and hindwing and right hind leg mounted on one slide (without number); head mounted in another slide (№ 6995); right antenna mounted in another slide (№ 6995); subgenital plate, gonapophyses, clunium, paraprocts and epiproct mounted in another slide (№ 6995). Thorax and remaining parts in a separate micro-vial with ethanol (MZSP 000215).

\section{REMARKS}

There was a slide (number 69277) in the collection labeled as holotype of Psococerastis interrupta New, 1972; this species was synonimized by Mockford (1981) to become a Junior synonym of Psococerastis opulenta (Navás, 1930).

\section{ACKNOWLEDGMENTS}

We thank Sônia Casari, curator of the collection of the Museu de Zoologia da Universidade de São Paulo, and Carlos José Einicker Lamas, of the same institution, for the facilities provided during our study and for access to the collection. AMSN and JAR thanks Instituto Nacional de Pesquisas da Amazônia (INPA) and Conselho Nacional de Desenvolvimento Científico e Tecnológico of Brazil (CNPq) for research support. AMSN thanks particularly the support for the Capes-INPA research grant (Process: 88887.312051/2018-00). JAR thanks particularly the support for the Cnpq research grant (Process: 300.997/2016-7). ANGA thanks Instituto de Biología, Universidad Nacional Autónoma de México, for continuous research support. We also thanks the Project Rede Bionorte: Biodiversidade de Insetos na Amazônia.

\section{REFERENCES}

Arnett, R.H. 2000. American insects: a handbook of the insects of America North

\author{
of Mexico. 2. ed. Boca Raton, CRC. 1003p.
}

Holotype: female, Brazil: Xavantina, dead palm fronds on ground, 21-26.I.1969, T.R. New. 
Badonnel, A. 1986. Psocoptéres de Colombie (Insecta, Psocoptera). Missions écologiques du Professeur Sturn (1956 á 1978). Spixiana, 9: 179-223.

International Commission on Zoological Nomenclature (ICZN). 1999. International Code of Zoological Nomenclature. Fourth edition, adopted by the International Union of Biological Sciences. London, International Trust for Zoological Nomenclature, The Natural History Museum. 306p.

Lienhard, C. \& Smithers, C.N. 2002. Psocoptera (Insecta). World Catalogue and Bibliography. Genève, Muséum d'Histoire Naturelle. 745p. (Instrumenta Biodiversitatis V).

Machado-Alisson, C.E. \& Papavero, N. 1962. Um novo gênero e uma nova espécie de Corrodentia do Brasil: Lenkoella neotropical (Reuterellinae, Elipsocidae). Papéis Avulsos do Departamento de Zoologia, 15: 311-315.

Mockford, E.L. 1981. Systematics of new world genera of Cerastipsocini and species of Psococerastis Pearman (Psocoptera: Psocidae: Cerastipsocinae). Transactions of the American Entomological Society, 107: 249-298.

Mockford, E.L. 1982. Redescription of the type species of Myopsocus, M. unduosus (Hagen) and resulting nomenclatural changes in genera and species of Myopsocidae (Psocoptera). Psyche, 89(3-4): 211-220.

Mockford, E.L. 1985. Forms, distribution, and relationships of Psocus coquilletti Banks (Psocodea: Psocidae). Southwestern Naturalist, 30(1): 13-22.

Mockford, E.L. 1991. New species and records of Psocoptera (Insecta) from Roraima State, Brazil. Acta Amazônica, 21: 211-317.

Mockford, E.L. 1996. New species and records of Psocoptera from northern Venezuela. Tropical Zoology, (Special issue 2): 1-98.

Mockford, E.L. 2000. A classification of the psocopteran Family Caeciliusidae (Caeciliidae auct.) Transactions of the American Entomological Society, 125(4): 325-417, 1999.

Mockford, E.L. 2005. A new genus of perientominae psocids (Psocoptera: Lepidopsocidae) with a review of the perientominae genera. Transactions of the American Entomological Society, 131: 201-215.

New, T.R. 1972. A collection of Psocidae (Psocoptera) from Central Brazil. Arquivos de Zoologia, S. Paulo, 22(4): 193-237.
New, T.R. 1973. South American species of Nepiomorpha Pearman and Notiopsocus Banks (Psocoptera). Entomologist, 106: 121-132.

New, T.R. 1975. Some Lepidopsocidae (Psocoptera) from Central Brazil. Revista Brasileira de Entomologia, 19(2): 85-95.

New, T.R. \& Thornton, I.W.B. 1975. Psocomorpha (Psocoptera) collected on recent expeditions to South America. Journal of Entomology, (B) 44(1): 27-80.

Silva-Neto, A.M. \& García Aldrete, A.N. 2015. Psocoptera. In: Catálogo Taxonômico da Fauna do Brasil. PNUD. Available at: http://fauna.jbri.gov. br/fauna/faunadobrasil/128. Access in: 08/01/2019.

Silva-Neto, A.M.; García Aldrete, A.N. \& Rafael, J.A. 2016. A storage method for 'Psocoptera' (Insecta: Psocodea) in "CD box". Entomobrasilis, 9: 220-223.

Silva-Neto, A.M.; Rafael, J.A. \& García Aldrete, A.N. 2014. New species of Triplocania Roesler with forewing M3 forked (Psocodea: 'Psocoptera': Ptiloneuridae), from Brazil. Zootaxa, 3838: 77-86. D0l

Smithers, C.N. 1972. The classification and phylogeny of the Psocoptera. Memoir Australian Museum, 14: 1-349.

Smithers, C.N. 1991. Psocoptera (Psocids, Booklice). In: CSIRO (Ed.). The Insects of Australia. A textbook for students and research workers. 2. ed. New York, Cornell University Press. v. 1, p. 412-420.

Yoshizawa, K. \& García Aldrete, A.N. 2010. Description of a new species of the Trichadenotecnum roesleri species group from Brazil (Insecta: Psocodea: "Psocoptera": Psocidae) and its phylogenetic implications. Studies on Neotropical Fauna and Environment, 45(1): 61-66.

Yoshizawa, K. \& Johnson, K.P. 2014. Phylogeny of the suborder Psocomorpha: congruence and incongruence between morphology and molecular data (Insecta: Psocodea: 'Psocoptera'). Zoological Journal of the Linnean Society of London, 171(4): 716-731.

Yoshizawa, K. \& Lienhard, C. 2010. In search of the sister group of the true lice: a systematic review of booklice and their relatives, with an updated checklist of Liposcelididae (Insecta: Psocodea). Arthropod Systematics and Phylogeny, 68: 181-195. 